\title{
LEGAL POLITICS IN THE AMENDMENT OF REGIONAL HEAD ELECTORAL LAW
}

\author{
Fayreizha Destika Putri, Ani Purwanti \\ Faculty of Law, Diponegoro University \\ fayreizhadp@gmail.com
}

\begin{abstract}
Legal politics means that in every legislations are the result of political calculation from actors in legislative-making. The political context regarding the issue such legislation is based upon has a profound effect in the changing course of that legislation. This paper explores the political calculation, thus legal politics, behind the promulgation of Pilkada (regional leader election) law. It is found that there are two fundamental context within the promulgation of Pilkada; civil society and political party. On the former issue, Pilkada law is intended to encourage more public participation in election as to which the system has been revolutionized into a direct type of election. Meanwhile, the political party tends sought a regulation that will ease their voter mobilization. However, the problem emerges when people starts disinterested with the election which has been stained with dirty competition and nepotism. One can argue that if this problem has not been solved in the foreseeable future, the negative impact will be a disarray of social harmony divided by politically-driven social categories.
\end{abstract}

Keyword: Legal Politics, Pilkada Law, Civil Society, Political Party

\section{Introduction}

Defining legal politics is not an easy task. To dissect such, politics, as explicated by Bismarck, means staking chances in order to thrive for a bigger benefit. In regard to legal politics, the definition could be quite perplexing as which is interpreted as either legal policy of politics of law. ${ }^{1}$ Politics is not only attributed to a purpose and means to achieve that purpose which can be handled by using instrumental rationale, but also conceived existential nature as to Weberian's value and rationality. ${ }^{2}$

Radhie conceptualized legal politics as a statement from the state rulers regarding the law which is in effect on state territorials and the direction which laws are expanded to. ${ }^{3}$ Mahfud gives a definition of legal politics as a form of legal policy which regulates the law. A law that regulates the lesser laws by which applicability is determined by in order to achieve state goals. ${ }^{4}$ In legal politics, every political elements which underlies the law and policy making processes have an essential role in progressively engineering the performances of state bodies in enacting legislations, state regulations, or policies. Legal politics also have an influential role in managing

\footnotetext{
${ }^{1}$ Bernard L. Tanya, Politik Hukum Agenda Kepentingan Bersama, (Yogyakarta: Genta Publishing,2011), 1.

${ }^{2}$ Ibid

3 Teuku Mohammad Radhie, "Pembaruan dan Politik Hukum dalam Rangka Pembangunan Nasional”, Majalah Prisma No. 6 Tahun II, Desember 1973: 3.

${ }^{4}$ Mahfud M.D., Politik Hukum di Indonesia (Revised Edition), (Jakarta: PT. Rajagrafindo Persada,2011), hlm. 2.
} 
the administrative and operational procedures within state bodies. Therefore, the implication of the importance of legal politics is its determinative power on the partiality and direction which regulation and policy are applied into.

In Indonesian Legal Politic, Pancasiala as the ideals of law has the constitutive and regulatitive function of the life of nation. All legislation must be derivation of the principles and values contained in Pancasila. The ideal Law is regulative means that Pancasila as the ideal of law as the base and the ideal prerequisites underliying any positive law, so that every substance of regulation legislation must not conflict with the values of Pancasila. While the function of the constitutive means that Pancasila as ideal law directs law on goals to be achieved by the state, so as not to be deffected law, law is atool of power so that its formation, as well as enforcement, has allways intervened. ${ }^{5}$

However, law cannot be separated from social subsystems. Politics often intervenes the creation and implementation processes of law, thus make its noteworthy to be questioned whether which social subsystem -between law and politics- is more powerful and has more supremacy in the state politics. How the politics can influence and intervene the law, and why politics is able to do such? Nevertheless, it is clear that the political system which underlies the foundation of state has a contribution in shaping the characteristic of the rule of law. ${ }^{6}$

The Republic of Indonesia is a state with presidential government with a twist. Despite the President has roles as both the head of state and head of government, the ruling political system guarantees a distribution of power into three bodies; executive, legislative, and judicial order. The first two of which are elected democratically and directly by Indonesia's adult, politically eligible, citizens, indicating a positive establishment of democracy in Indonesia.

Pilkada (pemilihan kepala daerah) or regional leader election is a democratic event in which citizens can vote for their desired candidates which are promoted and as a representative of one political party, the coalition of which, or merely independent, insofar as the candidate is eligible according to the enacted terms, conditions, and procedures of the election. In a post-Reformation era, the democratization process in Indonesia has been flourishing progressively. The growing influx of public political participation in such democratic event, for which the least is election, is conveyed through procedures which reflects accountability and equality values for every citizens.

\footnotetext{
${ }^{5}$ Retno Saraswati, "The Function of Ideal Law in Preparation Regulation Legislation in order to Creating Equitable Regional Development”, Diponegoro Law Review Vol. 02 Number 01, April 2017: 116

${ }^{6}$ Ibid, 9.
} 
Before 2005, the elections for regional executive leader such as gubernatorial and major were solely determined and deliberated by the regional congress or house of representative. However, the government had later enacted a more rigid electoral procedure through the Law No. 32/2004 on Regional Government in order to accelerate the democratization process in regionals by allowing the citizens to directly vote for electoral candidates. It is later promulgated by new legislation, the Law No. 22/2007 on Electoral Procedures in which Pilkada is included into the ruling regime of electoral law. The first Pilkada in Indonesia was the 2007 Jakarta gubernatorial election. In 2011, a new electoral law, the Law No. 15/2011, was enacted and replaced the old electoral system.

In February $17^{\text {th }}, 2015$, the Indonesia house of representative had passed a new Pilkada law through the Law No.1/2015 on Pilkada. Through this law, Pilkada was no longer held under representative voting. But instead, the new electoral law encouraged a public participation of the society -or citizens- in this direct election. However, given that electoral law has been constantly changed or amended in every four years, or the end period of presidency. It is reasonable to conclude that the constant change of electoral laws in Indonesia indicate an overwhelming influence from politics in the process-making. This constant of electoral law indicates a deliberate political strategy to perpetually problematize the ruling electoral law. Hence, it must be noted that this continual problematization of electoral laws and its subsequent effort to legalize a new rule may have posited uncertainty, criticism, and decline of popularity for the state rulers -executive and legislative- within the society. Nevertheless, the electoral procedure still pretty much prevails and guarantees political rights of citizen in regard to political participations, i.e. election.

Furthermore, the transition of power from the state to the people in Pilkada has opened up a sovereign space in which political opportunities accommodates people interests in voting their candidates in a direct, rigid, secretive, and self-determination procedures. This circumstance is promulgated in several legislations such as Law No. 1/2015 and Law no. 9/2015. Both of which are regulations that have been amended or replaced with new foundation, inquiry, and rationale throughout Indonesia history. The legislative revision is expected to promote a just democratic system.

The explanation above underlies the background of the study in this paper. This paper problematize the dynamics of legal politics which influences the making-process of electoral laws in Indonesia. Therefore, the research question which this paper is trying to answer is: what factors that influence the amendment of electoral laws, the Law No. 1/2015 into the Law No. 8/2011, in Indonesia? 


\section{The Legal Politics within the Promulgation of Pilkada Law}

After the promulgation of the Law No. 32/2004 on Regional Government and State Regulation No. 6/2005 on Election, Confirmation, and Termination Procedures of Gubernatorial and Mayor's Term, a new chapter of democracy in the history of political localization in Indonesia began. The Pilkada law implicates a stern endorsement of the state on democratization in which people is positioned above the preceded political games by the elite politicians which tends to dominate, hegemonize, and eventually, constrict the political rights of citizen.

The decision to establish a direct Pilkada was not coming all of a sudden and out of nothing. Many factors that contribute to its advancement on reinvigorating the democratic life of society. Direct democracy is a manifestation of sovereignty under the people. Its outcome is legitimized by the accumulation of direct supports from the people. This can implicates to the reduction of unethical political practices such as bribe, vote-rigging, or voter manipulation. Nevertheless, Pilkada is an inseparable part of the existing socio-political realm in the society which reflects its normative foundation such as social norms, moral, and religion.

Voluntary participation of the society in the democratic process of Pilkada is a positive indicator on assessing the progress of democratization as to voter rights, for instance. Although indeed that the people as law-abiding citizens can actively contribute in political participation, its outcome of democratization to achieve a moral and human politics depends on how political education is established beforehand. The role of which is important to safeguard the social harmony and respect of human rights in the society.

The form of political public participation in direct Pilkada can be seen in various type and agenda of political movements. Ranging from as an apolitical person or group, to observers, as well as to participants. As in the last two elections, there will be an apolitical people's percentage in the sense of being indifferent to the political process. In Indonesia, the percentage of apolitical people is still below $30 \%$ on average. While the observer form is the largest portion, those who exercise influence in the political process as a member of the organization, present in the campaign, and the voter. While in the form of participants, including the people involved as party activists, and interest groups. As activists, people's political participation has led to the degree of occupying positions of organization / politics.

Since the pilkada is an implementation of democracy, democratic values are the parameters of successful implementation of the activity process. These values are realized through direct electoral principles consisting of: direct, public, free, confidential, honest and fair. Political parties 
have a vested interest in making their candidates elected so that it is impossible to hand them over to them. Pilkada records have shown that the holding of elections by political parties has led to democratic biases, such as conspiracy, nepotism and money politics. Therefore, such activities shall be organized by strictly regulated institutions to safeguard and ensure the implementation of the values of openness, fairness and fairness.

The government and the House of Representatives agreed on the implementation of the Pilkada will be held simultaneously in December. The agreement was created after the organizers, namely the General Elections Commission (KPU), has agreed to undertake the task. KPU stated that 827 pairs of candidates for regional head have registered: 20 pairs of candidates for governor/vice-governor, 691 candidates for mayor/deputy mayor, and 116 candidates for mayor / deputy mayor. Among them there are 28 couples from individual lines who progress with capital bundles of identity cards of prospective voters.

In the Law No. 32/2004 on Regional Government, it is promulgated that Pilkada will be held in a form of direct voting by citizens, in which the candidates are promoted by a political party or coalition of several parties. Meanwhile, in the Article 59 (1b) Law No. 12/2008, the gubernatorial/mayor candidates can be promoted independently or by unaffiliated civil society. Ideally, the purpose of direct voting is to accelerate the realization of good governance as civil society now can be involved directly in the policy-making process. This proves that the distribution of power from central government has been decentralized. Therefore, the regional government is now becoming more autonomous from the central government.

The government has promulgated two laws regarding simultaneous national-level Pilkada. Those are the Law No. 8/2015 on the Amendment of the Law No. 1/2015 on the Promulgation of State Regulation in-lieu of Law No. 1/2014 on Gubernatorial, Regent, and Mayor Elections, and the Law No. 10/2016 on the Second Amendment of the Law No.1/2015. In the Law No. 8/2015, it is stipulated that, "the gubernatorial, regent, and mayor elections shall be held once in five years simultaneously in every territorials of the Republic of Indonesia." Furthermore, the election shall be held in two phases; preparation and execution. As stipulated in Article 5 (1) of Law No. 8/2015, the preparation phase consists of:

1) Program budgeting

2) Arranging election procedures

3) Planning the execution plan including procedures and schedules

4) Establishing PPK, PPS, KPPS, electoral supervisor bodies in regencies, sub-districts, PPL and electoral in-site supervisors. 
5) Announcement and Registration of electoral supervisors

6) Capitulation of potential voter lists

7) Recapitulation and updating voter lists

Meanwhile, the execution phase consists of:

1) Announcement of candidacy registrations in provincial, regency, and municipal level

2) Registration of the candidates

3) Confirmation of candidate's requirements

4) Confirmation and public announcement of the accepted candidates

In the Law No. 10/2016, there are crucial changes in the stipulation, those of which are:

\section{Expanding the authority of Electoral Supervisory Committee (Bawaslu)}

In this new regulation (article 10 (1b) and $135 \mathrm{~A}$ ), Bawaslu has given a further authority to give sanction against the candidate(s) who have violated regulation. Bawaslu is able to investigate the violation and if it is proven true, Bawaslu can sanction the candidate in a form of his/her disqualification from the election. Furthermore, this sanction is justified in Bawaslu's authority and duties in accepting, investigating, and sanctioning the complaint upon Bawaslu's decision regarding elections of gubernatorial, regent, and mayor candidates; election which proposed by the candidates and/or political parties, and the disqualification sanction and/or restriction to political parties/coalition in promoting the candidates for the next election.

\section{Registration and confirmation of candidates}

The registration of candidates must have gotten an affirmation from the leader of a political party which agreed to promote them to the candidacy. If there is a clash of interest between the candidates and the party in either regional or central level, thus the affirmation from the central management of political party will be prioritized.

\section{Selection of PPK and KPPS}

The Selection of members of PPK and KPPS is held openly with considerations on competency, capacity, integrity, and independency of the candidate member are taken by the executive board.

\section{Independent Candidate}

After the independent candidate has fulfilled its requirements, such as initial evidence of social supports by registering copies of IDs, the process of registration is then proceeded with factual verification. The verification is conducted through census method, meeting the supporters (as registered by their copied IDs). If the supporters are not able to present or 
meet the verifier, the temporal limitation is enacted which takes about three days. Otherwise, their supports will be considered invalid.

\section{Incumbent Problems}

It is stipulated in article 7 of Law No. 8/2015 that the candidates must not have been in conflict with the incumbent or current ruling leader. This implicates a chance of a political nepotism which then results in political dynasty, despite the law's guarantee of every citizens to be elected in the government. There are several factors which underlies this amendment, those of which are:

1) An urge of establishing a democratic Pilkada

2) Realizing a Pilkada which is in accordance or comply to six principles of election: direct, public, freedom, confidential, honesty, and fairness

3) Preventing biased practices in democracy, such as conspiracy, nepotism, and money politics

4) To assure the right to vote for eligible citizens

\section{Political Interests}

Changes to the Law on Pilkada in the amendment can not be denied there are interests that intervene both from government officials and from the public. For example in making the Election Law there is a debate about the election of regional heads to be elected by Parliament or will be elected directly by the people. Here the people are trying to get their right to be able to directly elect their own regional heads so that money politics games can be reduced because it is impossible to bribe voters in the millions of people. So there is a pulling here the interests of political institutions with the community.

Beyond the political forces that sit in government, there are other forces that contribute politically and influence the legal products that the government brings. Such strengths come from interest groups that are guaranteed and acknowledged to exist and their role according to the law as a democratic country, such as businessmen, scientists, community organizations, professional organizations, religious leaders, non-governmental organizations and others. The Law No. 10/2004 on the Establishment of Laws and Regulations affirmed the participation of the community which is stipulated in Article 53: "The public has the right to give suggestions orally or in writing in the framework of preparing or discussing the Draft Law and Draft of Regional Regulation". The fact above shows that the role of society in influencing the formation of the law, have a place and appreciation so vast 
I think this simultaneous change of elections uses the legal paradigm as a tool to serve the needs while the simultaneous elections are colored by this single candidate including the legal pardigma as a tool for social engineering. Because the Single Candidate is allowed by the decision of the Constitutional Court in advance with certain conditions. Changes to the Law on Pilkada in the changes can not be denied there are interests that intervene both from government officials and from the community. For example in making the Election Law there is a debate about the election of regional heads to be elected by Parliament or will be elected directly by the people. Here the people are trying to get their right to be able to directly elect their own regional heads so that money politics games can be reduced because it is impossible to bribe voters in the millions of people. So there is a pulling here the interests of political institutions with the community.

Furthermore, perhaps the most influential actors behind the amendment of Pilkada is political party. As they compete in the election by sponsoring candidates, then there must be certain interests that follow. However, regarding the promulgation of Pilkada law, the interest of political party is more focused on voter mobilization. Rosenstione and Hansen (1993) defined voter mobilization as a "process by which candidates, parties, activists, and groups induce other people to participate'. They emphasise the roles of actors such as parties, candidates, groups, and activists as the prime movers to encourage participation and to gain the support of other people. Voter mobilization will work if there are actors who propel the process despite it is not easy due to the high rate of public skepticism towards the election. As a one-way process, voter mobilization manipulates the flow of information from the candidates, parties, and activists to people in one orchestrated direction. Nettl (1967) took a different approach to voter mobilization by identifying it as a process which functions to articulate interests and to legitimate authority. He saw voter mobilisation as an interactive process performing two functions which are channeling interests and legitimizing authority. Regarding channeling, people can be mobilized if their interests are accommodated by political parties and candidates (Leighley, 1995: 192). For authority legitimacy, political parties and candidates get support from the people whom they mobilize. In the Pilkada, voter mobilisation is undertaken by political parties and candidates in various ways to get to win the election (Fraenkel \& Aspinall, 2013).

However, this method is susceptible to be misused as an electoral corruption. In practical, this mobilization is conducted by buying votes, voter obstruction, etc (Pratikno 2009: 76). In Indonesia, such practices are strictly prohibited and considered a criminal offence. Hence, the representatives (and their political parties) need a new strategy in mobilizing voter. In legislative politics, they also sought to redirect the purpose of Pilkada law which was intended to put the 
parties under heavy public scrutiny which the parties deemed as patronizing. The implication is a rise of new method in voter mobilization which the law will consider such as legally eligible to conduct. The representatives wanted to give the political parties more role in political education, by which the party can use as a form of voter mobilization. This new method seems has given a refreshing nuance and image which is politically beneficial to the party, thus distracting the public scrutiny from the scandal of electoral corruptions.

Although practices of voter mobilization are commonly frowned upon by society, its existence is inevitable due to the low rates of electoral participation. Nonetheless, election is about the people, not the party. Most of Indonesian voters are not loyal to the political party, they vote for the person they want irrespective of the political party, (Anggriani, N. et.al, 2014). Increased citizen participation can, indeed, make the policy-making process to be easier and more reliable to gauge the collective will of society, in turn enabling the local government to be more accountable and responsive. However, it must be noted that groups of people do not always have a meaningful collective will, and that participation can result in the increased involvement of interest groups. The increasing participation can instead increase the number of divergent voices rather than producing a collectively optimal governmental decisions. Despite the Law has eased the communication canal that once had gaped the local government and the citizens, an active mass participation can instead disarray the collective solidary of society upon an issue and makes them to be more divided and more confrontations (Strachan, 2014), thus a collective will that aligns the government and the society will be harder to achieve instead.

\section{Conclusion}

There are several deliberative factors which underlie the amendment of the Law No. 1/2015 into the Law No. 2015 and Law No. 10/2016, those of which are:

1) The democratization process

2) Sturdily implementing the Pilkada as a direct, popular, free, fair, confidential, and honest election.

3) Preventing bias practices that could stain the democracy, such as conspiracy, nepotism and money politics

4) Assuring citizens' right to vote and be voted through the election

Furthermore, there are political factors which transcend legal comprehension but can powerfully influence the amendment, those of which are citizens and political party. On one hand, citizens have an important role in regard to accountability and responsiveness. They can make a 
collective political movement which legitimize and sustain their political bargaining power in the electoral competition, thus Pilkada. On the other hand, the political demands the amendment in order to re--direct the regulation regarding voter mobilization by proposing an increased role of political party to promote political education and electoral information, which can be deemed as a new form of voter mobilization. The implication is positive as the political parties, the government, and the citizens are starting to be politically cooperative mutually. However, criticism must be noted here as the increasing nature of public political participation is two side of a coin. On one hand, it can encourage a direct public participation in governmental policy-making process by the citizens. On the other hand, it is susceptible to an orchestrated social division caused by ideological and political allegiances, thus instead of bringing the society to be more cohesive, they tends to be more divided than ever.

\section{References}

MD, Mahfud. (2011). Politik Hukum di Indonesia (Revised Edition). Jakarta: PT. Rajagrafindo Persada.

Retno Saraswati. (2017). The Function of Ideal Law in Preparation Regulation Legislation in order to Creating Equitable Regional Development. Diponegoro Law Review, 02 (01), 116.

Tanya, Bernard L. (2001). Politik Hukum Agenda Kepentingan Bersama. Yogyakarta: Genta Publishing.

Teuku Mohammad Radhie. (1973). Pembaruan dan Politik Hukum dalam Rangka Pembangunan Nasional. Majalah Prisma, 02 (06), 3.

Undang-Undang Nomor 8 Tahun 2015 tentang Perubahan Atas Undang-Undang Nomor 1 Tahun 2015 tentang Penetapan Peraturan Pemerintah Pengganti Undang-Undang Nomor 1 Tahun 2014 tentang Pemilihan Gubernur, Bupati dan Walikota Menjadi Undang-Undang.

Undang-Undang Nomor 10 Tahun 2016 tentang Perubahan Kedua Atas Undang-Undang Nomor 1 Tahun 2015 